\title{
Effect of some Abiotic Factors on the Growth and Development of Different Pleurotus spp.
}

\author{
Naresh Kumar Bhadana ${ }^{1}$, Gopal Singh ${ }^{1}$, Deepak Kumar ${ }^{1}$ and Seweta Srivastava ${ }^{2^{*}}$ \\ ${ }^{1}$ College of Agriculture, S.V.B.P. University of Agri. \& Tech., Meerut, U.P., India \\ ${ }^{2}$ School of Agriculture, Lovely Professional University, Phagwara, Punjab, India
}

*Corresponding author

\section{Keywords}

Growth regulators, Mushroom,

Pleurotus spp., Sugar, Temperature

Article Info

Accepted:

10 September 2020

Available Online:

10 October 2020

\section{A B S T R A C T}

Mushrooms need carbon and nitrogen for structural and functional purposes in addition to trace elements, growth regulators and vitamins. Therefore, evaluation of their role in influencing the growth of the mushroom is a necessary aspect to be studied. The influences of sugar, temperature and growth regulators were investigated during this experiment on the mycelium growth of different species of oyster mushroom viz., P. florida, $P$. flabellatus, $P$. djamor and $P$. eryngii. The results of the present experiment indicated that maximum radial growth was found in glucose followed by maltose. $P$. djamor and $P$. eryngi exhibited highest radial growth $(90.00 \mathrm{~mm})$ at the temperature of $29^{\circ} \mathrm{C}$ followed by $P$. florida $(83.50 \mathrm{~mm})$. Whereas $P$. flabellatus $(78.00 \mathrm{~mm})$ showed maximum radial growth at $26^{\circ} \mathrm{C}$. Maximum radial growth of Pleurotus spp. was recorded at $5 \mathrm{ppm}$ and $10 \mathrm{ppm}$ concentration of gibberellic acid and indolbutaric acid. So, it was concluded that we can increase the vegetative growth of Pleurotus spp. by adding glucose, maltose as sugar along with growth regulators like gibberellic acid and indolbutaric acid.

\section{Introduction}

Pleurotus spp. has a great commercial potential being an edible and wood decaying fungus (Kaur and Atri, 2016). Mushrooms that are edible known as food of Gods also used delicacy or garnish and eaten routinely as in human diet generally known as healthy food (Memon et al., 2017; Singh et al., 2018).
Mushrooms considered as a good source of vitamins, which are essential for human diet including vitamin $\mathrm{C}$, niacin, and riboflavin. Dhingri (Pleurotus spp.) Oyster mushrooms are mostly found in India (Ahmed et al., 2009).

Pleurotus genus is one of most extensively studied white-rot fungi due to its exceptional 
ligninolytic properties. It is an edible mushroom and it also has several biological effects, as it contains important bioactive molecules. In basidiomycete fungi, lignocellulolytic enzymes are affected by many typical fermentation factors, such as medium composition, ratio of carbon to nitrogen, $\mathrm{pH}$, temperature, air composition, etc (Kadiri and Kehinde, 1999). The survival and multiplication of mushrooms is related to a number of factors, which may act separately or have interactive effects among them (Bellettini et al., 2019).

Mushroom production has been limited throughout the world due to incompetence; incapability and lack of technical knowledge to culture edible mushrooms. Spawn (active mycelium) production is one of the major limiting factors to mushroom cultivation all over the world (Stanley, 2010). The high temperatures between $27^{\circ} \mathrm{C}$ and $35^{\circ} \mathrm{C}$ during the day has been a major problem for the farmers of tropical regions who wish to grow mushrooms (Gaitán and Salmones, 2008).

So, in the present experiment, influences of different sugars, temperature range and growth regulators were investigated on the mycelium growth of different species of oyster mushroom viz., $P$. florida, $P$. flabellatus, $P$. djamor and $P$. eryngii.

\section{Materials and Methods}

The experiments were conducted in Mushroom Laboratory of Department Plant Pathology, S. V. P. University of Agriculture \& Technology, Meerut, U.P. on the Western side of the Delhi-Dehradun high way at a distance of $10.0 \mathrm{~km}$ away in the north of Meerut city.

\section{Establishment of pure culture}

The culture of different species of Pleurotus viz., P. florida, P. flabellatus, P. djamor and
$P$. eryngii included in the present investigation were collected from Mushroom Research and Training Centre, G. B. P. U. A. \& T, Pantnagar and C.S.A.U.A \&T, Kanpur. The cultures of Pleurotus species obtained were further purified by single hyphal tip method. For this purpose, the cultures were grown in sterilized petri plate on potato dextrose agar (PDA) for 4-5 days. Single branched hyphae from the periphery of the growing colony were marked under low power $(10 \mathrm{X})$ in the compound microscope and transferred to PDA slants for maintenance. These tubes were incubated at $25-27^{0} \mathrm{C}$ for about a week, again subculture on PDA and then stored in a refrigerator at 2$10^{0} \mathrm{C}$ for further use.

\section{Effect of sugar solutions on radial growth and dry mycelial weight}

Different sugar solutions were used to study their effect on radial and dry mycelial growth. One percent solutions of glucose, sucrose, maltose, fructose and starch were mixed in sterilized media. The $\mathrm{pH}$ of the solutions was adjusted to 6.5-7.0 and spore suspension made in each solution was incubated at $25 \pm 1^{0} \mathrm{C}$. The $20 \mathrm{ml}$ medium was poured in each sterilized petri plate and subsequently inoculated with $5 \mathrm{~mm}$ disc of 10 days old culture. Inoculated plates were incubated at $25 \pm 1^{\circ} \mathrm{C}$ and observation for radial growth was recorded on eight day when the colony covered the first full plate. Observations on radial and dry mycelial growth were recorded.

\section{Effect of different temperature on radial growth}

For studies on variability, the culture of four Pleurotus species (i.e. P. djamor, P. florida, $P$. flabellatus and P.eryngii) were incubated at five different temperature viz. 20, 23, 26, 29,32 and $35^{\circ} \mathrm{C}$. Petri plates containing $20 \mathrm{ml}$ of sterilized PDA medium were inoculated at the centre with $9 \mathrm{~mm}$ diameter disc from 10 
days old actively growing mycelium under aseptic conditions. Four replications for each treatment were maintained. Observations on radial growth were taken at each $72 \mathrm{hrs}$ till the colony covered the first full plate.

\section{Effect of growth regulator on radial mycelial growth}

For the present investigation two growth regulators viz. Gibbrellic Acid (GA) and Indole Butaric Acid (IBA) were carried out at different concentrations i.e. 05 ppm, 10ppm, $15 \mathrm{ppm}$, and $20 \mathrm{ppm}$ on potato dextrose agar (PDA) medium for radial growth. PDA medium was prepared and required amount of growth regulators were added in the medium after sterilization. The $25 \mathrm{ml}$ medium was poured in each sterilized Petri plate and subsequently inoculated with $9 \mathrm{~mm}$ disc of seven days old culture of Pleurotus spp. like $P$ florida, $P$ djamor, $P$ flabllatus, $P$. eryngii. Inoculated plates were incubated at $25 \pm 1{ }^{0} \mathrm{C}$. The observations of radial growth were taken at each 72 hrs till the colony covered the first full plate.

\section{Statistical analysis of data}

Data with appropriate transformations were analyzed with the help of analysis of variance table wherever required. The $F$ value was tested and critical difference (CD) was calculated at 5 per cent of significance for comparing treatment means (Gomez and Gomez, 1996; Chandel, 2002).

\section{Results and Discussion}

\section{Effect of different sugar solution on radial growth}

Four species of Pleurotus spp. (i.e. P. Florida $P$. djamor, $P$. flabllatus and $P$. eryngii) were grown in five sugar solution viz. fructose, maltose, sucrose, starch and glucose, as shown in Table 1. The results revealed that maximum dry mycelial growth was found in glucose $(90.00 \mathrm{~mm})$ followed by maltose $P$. djamor. While in P. florida maximum radial growth in glucose $(90.00 \mathrm{~mm})$ followed in sucrose $(87.00 \mathrm{~mm})$. In case of $P$. flabellatus maximum radial growth in glucose $(88.30 \mathrm{~mm})$ followed in fructose $(88.00 \mathrm{~mm})$.in $P$. eryngii maximum radial growth was observed in glucose $(90.00 \mathrm{~mm})$ and followed in maltose sugar $(83.00 \mathrm{~mm})$. Minimum mycelial growth of each species varied significantly in all the sugar. The least growth was recorded in starch on which mycelial growth $(78.00 \mathrm{~mm})$ obtained in $P$. florida. In $P$. djamor (78.66mm sucrose) $P$. florida (78.00 mm starch), P.flabllatus $(80.00 \mathrm{~mm}$ starch) and P. eryngii (80.66 mm fructose).

Sastre-Ahuatzi et al., (2007) studied that the radial growth rate was evaluated in five strains of Pleurotus ostreatus, grown on starch-based and glucose-based agar media containing different concentrations. The radial growth rate of some strains showed a positive and a negative correlation with the productivity.

\section{Effect of different sugar solution on dry} mycelial growth

Four species of Pleurotus spp. (i.e. P. florida, $P$. djamor, P. flabllatus and P. eryngii) were grown in five sugar solution with PDB viz., fructose, maltose, sucrose, starch and glucose, as shown in Table 2. Maximum dry mycelial growth was found in glucose $(5.70 \mathrm{mg}$.) in $P$. flabellatus. In case of Pleurotus djamor maximum dry mycelial growth in glucose (5.59 mg.) followed by fructose $(5.36 \mathrm{mg}$.). In $P$. florida maximum mycelial growth in glucose $(4.77 \mathrm{mg}$.) followed in maltose (4.31mg.). In case of $P$. eryngii maximum mycelial growth was observed in sucrose (4.95mg.) followed in glucose sugar (4.45mg.). The least growth of the Pleurotus 
spp. were recorded in starch on which mycelial growth (2.28mg.) obtained in $\mathrm{P}$. djamor, $P$. florida (2.34mg.starch), $P$. flabllatus (3.74mgmaltose) and $P$. eryngii (3.13mg. fructose).

Gbolagade et al., (2006) Revealed that the greatest biomass Among the monosaccharide, glucose stimulated the best biomass production $(186.7 \mathrm{mg} / 30 \mathrm{~cm} 3)$ followed in order by fructose mannose, and sorbose $(\mathrm{P}<=0.05)$. In the series of complex sugars and sugar alcohols, mannitol supported the highest biomass yield with mycelial dry weight of $130.0 \mathrm{mg} / 30 \mathrm{~cm} 3$. The maximum biomass yield $(330.0 \mathrm{mg} / 100 \mathrm{~cm} 3)$ was obtained when $7.0 \mathrm{~cm} 3$ of $P$. florida inoculum was inoculated into a submerged medium.

\section{Effect of temperature on radial growth}

Experiment was conducted to study the effect of range of temperatures $\left(20-35^{0} \mathrm{C}\right)$ on the radial growth of four Pleurotus species (i.e. $P$. florida, $P$. flabellatus, $P$. eryngii and $P$ djamor). As shown in Table 3, $P$. djamor and $P$ eryngi exhibited highest radial growth $(90.00 \mathrm{~mm})$ at the temperature of $29^{\circ} \mathrm{C}$ followed by $P$. florida $(83.50 \mathrm{~mm})$ which is at par with each other. Whereas P. flabellatus $(78.00 \mathrm{~mm})$ showed maximum radial growth at $26^{\circ} \mathrm{C}$. At $35^{\circ} \mathrm{C}$ the radial growth of $P$. djamor, $P$. eryngi and $P$ florida were $69.25 \mathrm{~mm}, 59.75 \mathrm{~mm}$, and $65.25 \mathrm{~mm}$, respectively while $P$. flabellatus could not grow at $35^{\circ} \mathrm{C}$. While P.flabellatus exhibited minimum radial growth $(40.50 \mathrm{~mm})$ at the temperature of $32^{0} \mathrm{C}$ followed by $P$. djamor $(42.00 \mathrm{~mm})$ at the temperature $20^{\circ} \mathrm{C}$.

Baliyan (2008) found also a range of temperature $\left(25-30^{0} \mathrm{C}\right)$ to be suitable for mycelial growth of five Pleurotus spp. Radial growth of $P$. florida and $P$. sapidus were found maximum at $30^{\circ} \mathrm{C}$ where as the growth of $P$. sajor caju, $P$. fossulatus and $P$. flabellatus was maximum at $25^{\circ} \mathrm{C}$. Zharare et al., (2010) studied the sensitivity of Pleurotus mycelium to different temperature range. Eight Pleurotus spp., which included P. sajor caju and $P$. eryngii were cultured aseptically on agar at 25,30 and or $35^{\circ} \mathrm{C}$. Mycelial growth was maximum at $25-30^{\circ} \mathrm{C}$ whereas a temperature of $35^{\circ} \mathrm{C}$ was detrimental to mycelial growth except in one strain. At the highest temperature tested $\left(35^{\circ} \mathrm{C}\right)$, the relative mycelial growth rate ranged from 6 to $91 \%$, indicating marked differences in tolerance of the strains to high temperature. Sardar et al., (2015) also reported that Pleurotus species were cultured aseptically on PDA at different temperature ranges and found mostly Pleurotus species grows best at $25^{\circ} \mathrm{C}$.

\section{Effect of growth regulators on radial growth}

As shown in data presented in (Table 4) maximum radial growth $(89.00 \mathrm{~mm})$ in $P$. djamor was recorded on $8^{\text {th }}$ day of observation at Gibberellic acid10 ppm concentration followed by $5 \mathrm{ppm}$ concentration $(85.66 \mathrm{~mm})$. In case of Indol butyric acid at $5 \mathrm{ppm}$ concentration (45.66 $\mathrm{mm}$ ) followed by $10 \mathrm{ppm}$ concentration $(33.33 \mathrm{~mm})$. Similarly, in case of Gibberellic acid maximum radial growth of $P$. florida on $8^{\text {th }}$ day observed at $5 \mathrm{ppm}$ concentration $(90.00 \mathrm{~mm})$ followed by $10 \mathrm{ppm}$ concentration $(84.33 \mathrm{~mm})$ and in case of Indol butaric acid at $5 \mathrm{ppm}$ concentration $(63.00$ $\mathrm{mm}$ ) followed by $10 \mathrm{ppm}$ concentration $(42.66 \mathrm{~mm})$. In case of Gibberellic acid maximum radial growth of $P$. flabllatus on $8^{\text {th }}$ day observation at $10 \mathrm{ppm}$ concentration $(90.00 \mathrm{~mm})$ followed by the $20 \mathrm{ppm}$ concentration $(85.66 \mathrm{~mm})$ and in case of Indol butaric acid maximum radial growth at $5 \mathrm{ppm}$ concentration $(48.66 \mathrm{~mm})$ followed by $10 \mathrm{ppm}$ concentration. 
Table.1 Effect of sugar solution on radial growth (mm) of different Pleurotus species on PDA

\begin{tabular}{|c|c|c|c|c|c|c|c|c|c|}
\hline \multirow[b]{2}{*}{ S. No. } & \multirow[b]{2}{*}{$\begin{array}{c}\text { Sugar } \\
\text { solution }\end{array}$} & \multicolumn{2}{|c|}{ P. djamor } & \multicolumn{2}{|c|}{ P. florida } & \multicolumn{2}{|c|}{ P. flabellatus } & \multicolumn{2}{|c|}{ P. eryngii } \\
\hline & & $\begin{array}{l}\text { Radial } \\
\text { growth } \\
\text { (mm) }\end{array}$ & $\begin{array}{c}\text { Radial } \\
\text { growth rate } \\
(\mathrm{mm} / \mathrm{day})\end{array}$ & $\begin{array}{c}\text { Radial } \\
\text { growth } \\
(\mathbf{m m})\end{array}$ & $\begin{array}{c}\text { Radial } \\
\text { growth rate } \\
(\mathrm{mm} / \mathrm{day})\end{array}$ & $\begin{array}{l}\text { Radial } \\
\text { growth } \\
(\mathrm{mm})\end{array}$ & $\begin{array}{c}\text { Radial } \\
\text { growth rate } \\
\text { (mm/day) }\end{array}$ & $\begin{array}{l}\text { Radial } \\
\text { growth } \\
\text { (mm) }\end{array}$ & $\begin{array}{c}\text { Radial } \\
\text { growth rate } \\
(\mathrm{mm} / \mathrm{day})\end{array}$ \\
\hline 1 & Fructose & 82.00 & 10.25 & 78.66 & 9.83 & 88.00 & 11.00 & 80.66 & 10.08 \\
\hline 2 & Maltose & 83.66 & 10.45 & 79.33 & 9.91 & 85.33 & 10.66 & 83.00 & 10.37 \\
\hline 3 & Sucrose & 78.66 & 9.83 & 87.00 & 10.87 & 87.33 & 10.91 & 81.66 & 10.20 \\
\hline 4 & Starch & 80.66 & 10.08 & 78.00 & 9.75 & 80.00 & 10.00 & 82.00 & 10.25 \\
\hline 5 & Glucose & 90.00 & 11.25 & 90.00 & 11.25 & 88.30 & 11.04 & 90.00 & 11.25 \\
\hline 6 & control & 78.00 & 9.75 & 77.66 & 9.70 & 82.33 & 10.29 & 80.00 & 10.00 \\
\hline \multicolumn{10}{|c|}{$\begin{array}{l}\text { C.Dspecies1.0511 } \\
\text { sugar } \quad 1.2873 \\
\text { speciesxsugar } 2.575\end{array}$} \\
\hline
\end{tabular}

Average of three replications

Values in each vertical column followed by same letter(s) do not differ significantly 
Int.J.Curr.Microbiol.App.Sci (2020) 9(10): 1079-1088

Table.2 Effect of different sugar solution on weight of dried mycelium (mg/50 ml) of Pleurotus species in PDA broth

\begin{tabular}{|c|c|c|c|c|c|}
\hline S. No. & Sugar Solution & P. djamor & P. florida & P. flabellatus & P. eryngii \\
\hline 1. & Fructose & 5.36 & 3.95 & 4.10 & 3.13 \\
\hline 2. & Maltose & 4.94 & 4.31 & 3.74 & 4.36 \\
\hline 3. & Sucrose & 4.09 & 3.84 & 4.31 & 4.95 \\
\hline 4. & Starch & 2.28 & 2.34 & 5.31 & 4.03 \\
\hline 5. & Glucose & 5.59 & 4.77 & 5.70 & 4.45 \\
\hline 6. & Control & 4.05 & 4.06 & 3.96 & 4.04 \\
\hline $\begin{array}{l}\text { CD at5\% } \\
\text { sugar } \\
\text { speciesxsu }\end{array}$ & $\begin{array}{c}\text { cies0.1192 } \\
0.1460 \\
\mathbf{r} 0.292\end{array}$ & & & & \\
\hline
\end{tabular}


Table.3 Effect of different temperature on radial growth (mm) of different Pleurotus species

\begin{tabular}{|c|c|c|c|c|c|c|c|c|c|}
\hline \multirow[b]{2}{*}{ S.No. } & \multirow[b]{2}{*}{$\begin{array}{c}\text { Temp. } \\
\left({ }^{0} \mathrm{C}\right)\end{array}$} & \multicolumn{2}{|c|}{ P. djamor } & \multicolumn{2}{|c|}{ P. florida } & \multicolumn{2}{|c|}{ P. flabellatus } & \multicolumn{2}{|c|}{ P. eryngii } \\
\hline & & $\begin{array}{c}\text { Radial } \\
\text { growth } \\
(\mathrm{mm})\end{array}$ & $\begin{array}{c}\text { Radial } \\
\text { growth rate } \\
(\mathrm{mm} / \mathrm{day})\end{array}$ & $\begin{array}{c}\text { Radial } \\
\text { growth } \\
\text { (mm) }\end{array}$ & $\begin{array}{c}\text { Radial } \\
\text { growth rate } \\
\text { (mm/day) }\end{array}$ & $\begin{array}{c}\text { Radial } \\
\text { growth } \\
(\mathrm{mm})\end{array}$ & $\begin{array}{c}\text { Radial } \\
\text { growth rate } \\
(\mathrm{mm} / \mathrm{day})\end{array}$ & $\begin{array}{c}\text { Radial } \\
\text { growth } \\
(\mathrm{mm})\end{array}$ & $\begin{array}{c}\text { Radial } \\
\text { growth rate } \\
(\mathrm{mm} / \mathrm{day})\end{array}$ \\
\hline 1. & 20 & 42.00 & 5.25 & 67.75 & 8.46 & 61.75 & 7.71 & 70.00 & 8.75 \\
\hline 2. & 23 & 58.00 & 7.25 & 71.75 & 8.96 & 71.75 & 8.96 & 75.75 & 9.46 \\
\hline 3. & 26 & 64.00 & 8.00 & 83.50 & 10.43 & 78.00 & 9.75 & 81.25 & 10.15 \\
\hline 4. & 29 & 90.00 & 11.25 & 88.50 & 11.06 & 65.75 & 8.21 & 88.50 & 11.06 \\
\hline 5. & 32 & 75.50 & 9.43 & 79.50 & 9.93 & 40.50 & 5.68 & 78.50 & 9.81 \\
\hline 6 & 35 & 69.25 & 8.65 & 65.25 & 8.15 & 0 & 0 & 59.75 & 7.46 \\
\hline $\begin{array}{l}\text { CD at5 } \\
\text { Temp. } \\
\text { Temp }\end{array}$ & $\begin{array}{r}1.13 \\
13 \\
\text { iesies.269 }\end{array}$ & 0.9263 & & & & & & & \\
\hline
\end{tabular}

Values in each vertical column followed by same letter(s) do not differ significantly 
Table.4 Effect of growth regulator on radial growth (mm) of different Pleurotus species on PDA

\begin{tabular}{|c|c|c|c|c|c|c|c|c|c|}
\hline \multirow[b]{2}{*}{ S. No. } & \multirow[b]{2}{*}{ Growth regulator } & \multicolumn{2}{|c|}{ P. djamor } & \multicolumn{2}{|c|}{ P. florida } & \multicolumn{2}{|c|}{ P. flabellatus } & \multicolumn{2}{|c|}{ P. eryngii } \\
\hline & & $\begin{array}{l}\text { Radial } \\
\text { growth } \\
(\mathrm{mm})\end{array}$ & $\begin{array}{l}\text { Radial } \\
\text { growth } \\
\text { rate } \\
(\mathbf{m m} / \text { day })\end{array}$ & $\begin{array}{l}\text { Radial } \\
\text { growth } \\
(\mathrm{mm})\end{array}$ & $\begin{array}{l}\text { Radial } \\
\text { growth } \\
\text { rate } \\
(\mathrm{mm} / \mathrm{day})\end{array}$ & $\begin{array}{l}\text { Radial } \\
\text { growth } \\
(\mathrm{mm})\end{array}$ & $\begin{array}{l}\text { Radial } \\
\text { growth } \\
\text { rate } \\
(\mathbf{m m} / \text { day })\end{array}$ & $\begin{array}{l}\text { Radial } \\
\text { growth } \\
(\mathrm{mm})\end{array}$ & $\begin{array}{l}\text { Radial } \\
\text { growth } \\
\text { rate } \\
\text { (mm/day) }\end{array}$ \\
\hline 1 & GA@5PPM & 85.66 & 10.70 & 90.00 & 11.25 & 82.33 & 10.29 & 90.00 & 11.25 \\
\hline 2 & GA@0PPM & 89.00 & 11.12 & 84.33 & 10.54 & 90.00 & 11.25 & 82.00 & 10.25 \\
\hline 3 & GA @ 15PPM & 84.66 & 10.58 & 83.66 & 10.45 & 85.33 & 10.66 & 71.66 & 8.95 \\
\hline 4 & GA @0PPM & 83.33 & 10.41 & 84.00 & 10.50 & 85.66 & 10.70 & 69.00 & 8.62 \\
\hline 5 & IBA@ @PPM & 45.66 & 57.07 & 63.00 & 7.87 & 48.66 & 6.08 & 54.33 & 6.79 \\
\hline 6 & IBA@10PPM & 33.33 & 4.16 & 42.66 & 5.33 & 35.00 & 4.37 & 42.00 & 5.25 \\
\hline 7 & IBA@15PPM & 21.00 & 2.62 & 34.33 & 4.29 & 19.00 & 2.37 & 31.33 & 3.91 \\
\hline 8 & IBA@ @20PPM & 0 & 0 & 0 & 0 & 0 & 0 & 0 & 0 \\
\hline 9 & Control & 80.00 & 10 & 81.33 & 10.16 & 78.66 & 9.83 & 63.00 & 7.87 \\
\hline \multicolumn{10}{|c|}{$\begin{array}{ll}\text { CDspecies } & 0.8240 \\
\text { regulator } & 1.2360 \\
\text { speciesxregulator } & 2.472\end{array}$} \\
\hline
\end{tabular}

repliAverage of four replications

Values in each vertical column followed by same letter(s) do not differ significantly 
In case of Gibberellic acid maximum radial growth of $P$. eryngii on at 5ppm concentration $(90.00 \mathrm{~mm})$ and in case of Indol butaric acid maximum radial growth at $5 \mathrm{ppm}$ concentration $(54.33 \mathrm{~mm})$ followed by 10 ppm concentration $(42.00 \mathrm{~mm})$. The poorest growth was recorded on Gibberellic acid in $P$. djamor $(83.33 \mathrm{~mm}), P$. florida $(83.66 \mathrm{~mm}), P$. flabllatus $(82.33 \mathrm{~mm})$ and P.eryngii $(69.00$ $\mathrm{mm})$ and in Indol butaric acid $P$. djamor $(21.00 \mathrm{~mm}), \quad P$ florida $(34.33 \mathrm{~mm}), \quad P$. flabllatus $(19.00 \mathrm{~mm})$ and P.eryngii $(31.33$ $\mathrm{mm})$.

The results are in accordance to Guanxi et al., (2004) studied the effect of growth regulators gibberellic acid, kinetin, 2,4- D and 6- BA (6 benzyladenine) on mycelial growth of $P$. eryngii. The best combination for mycelia growth was found $2 \times 10-6 \mathrm{gm} / \mathrm{liter} \mathrm{GA}+$ 20x10-6 g /liter 2,4-D+ 1x10-6 g/liter 6-BA. This combination increased the activities of cellulose, polyphenol oxidase, amylase and catalase. This combination was mixed with the culture substrate, hyphal growth and fruit bodies appeared earlier and mushroom yield and biological efficiency of $P$. eryngii increased. Mukhopadhyay et al., (2005) evaluate the plant growth hormone viz. indole-3-acetic acid (IAA), gibberellic acid (GA3) and kinetin for biomass production of $P$. sajor-caju. The hormone, at different concentrations, increased the biomass of $P$. sajor-caju by 15-26\%. Maximum enhancement was observed with IAA.

In conclusion, the mycelium growth of oyster mushroom was affected by different sugars, temperature conditions and growth regulators. The results obtained in the present study revealed that gibberellic acid and IAA at 5 $\mathrm{ppm}$ and $10 \mathrm{ppm}$ concentration supported the maximum vegetative growth of different species of oyster mushroom. The present findings have helped us to understand the biochemical and temperature requirements of
Pleurotus spp. for enhancing the vegetative growth of this mushroom in the basal medium.

\section{References}

Ahmed SA, Kadam JA, Mane VP, Patil SS, Baig MMV. (2009). Biological efficiency and nutritional contents of Pleurotus florida mont singer cultivated on on different agro- wastes. Nature and Sci., 7: 1545-0740.

Baliyan N (2008). Study of genetic variability, spawn quality and interspecific hybridization on Pleurotus species. SVPUA\&T, Meerut. 34-56.

Bellettini MB, Fiorda, FA, Maieves HA, Teixeira GL, Ávila S, Hornung PS, Júnior AM, Ribani RH (2019). Factors affecting mushroom Pleurotus spp. Saudi Journal of Biological Sciences, 26(4): 633-646.

Chandel, S. R. S. 2002. A handbook of agricultural statistics. 2002 Edn. Achal Prakashan Mandir, India. Pp. A-99 - A101.

Gaitán HR and Salmones D (2008). Obtaining and characterizing Pleurotus ostreatus strains for commercial cultivation under warm environmental conditions. Scientia. Hortic. 118: 106-110.

Gbolagade J, Sobowale A and Adejoye D (2006). Optimization of submerged culture conditions for biomass production in Pleurotus florida (Mont.) Singer, a Nigerian edible fungus. African Journal of Biotechnology,5(16): 1464-1469.

Gomez, K.A. and Gomez, A.A. (1996). Statistical Procedures for Agricultural Research. An International Rice Research Institute Book, A WileyInterscience Publication, John Wiley \& Sons, New York.

Guanxi L, Gung SS and Juan LY (2004). Effect of different hormone on growth 
and yield of Pleurotus eryngii var. nebrodensis. Edible Fungi of China, 23(2): 37-38.

Kadiri M and Kehinde IA (1999). Production of grain mother and planting spawns of Lentinus subnudus. Niger. J. Bot.12: 3744.

Kaur B and Atri NS (2016). Effect of growth regulators and trace elements on the vegetative growth of Pleurotus sapidus Quél. Int J Pharm Pharm Sci, 8(11): 283-287.

Memon AA, Mangrio GS, Kaleri AA, Kumar B, Khan M, Kaleri RR, Hubdar Ali Kaleri HA, Kaleri, SH and Wahocho NA (2017). Effect of Dextrose Sugar on the Growth and Production of Oyster Mushroom (Pleurotus ostreatus) through Tissue Culture. Journal of Basic \& Applied Sciences, 13: 139-142.

Mukhopadhyay R, Chatterjee S, Chatterjee BP and Guha AK (2005). Enhancement of biomass production of edible mushroom $P$. sajor caju grown in whey by plant hormones. Process Biochem., 40(3): 1241-1244.

Sardar H, Ali MA, Ayyub CM and Ahmad R
(2015). Effects of different culture media, temperature and $\mathrm{pH}$ levels on the growth of wild and exotic Pleurotus species. Pak. J. Phytopathol., 27(02): 139-145.

Sastre-Ahuatzi M et al., (2007). Mycelial growth of strains of Pleurotus ostreatus developed on agar and its correlation with the productivity in pilot production farm. Braz. J. Microbiol. 38(3):568572.

Singh VP, Singh G, Kumar B, Kumar A and Srivastava S (2018). Effect of various chemicals on the mycelial growth and fruiting body of milky mushroom (Calocybe indica). Asian J. Crop Sci., 10: $168-173$.

Stanley OH and Awi-Waadi G (2010). Effect of substrates of spawn production on Mycelia of Oyster Mushroom species. Res. J. Appl. Sci. 5: 161-164.

Zharare GE, Kabanda SM and Poku JZ (2010). Effects of temperature and hydrogen peroxide on mycelial growth of eight Pleurotus strains. Scientia Horticulturae, 125(2): 95-102.

\section{How to cite this article:}

Naresh Kumar Bhadana, Gopal Singh, Deepak Kumar and Seweta Srivastava. 2020. Effect of some Abiotic Factors on the Growth and Development of Different Pleurotus spp.. Int.J.Curr.Microbiol.App.Sci. 9(10): 1079-1088. doi: https://doi.org/10.20546/ijcmas.2020.910.129 